\title{
ANALYSIS OF PLANTS INCLUDED INTO LITHUANIAN RED BOOK
}

\author{
Jolanta Margelienè, Aušra Budrienè \\ Kaunas University of Applied Sciences, Faculty of Landscaping \\ Department of Green Plantations and Agrotechnologies \\ Mokslo st. 2, Mastaičiai, 53313 Kaunas reg. \\ E-mail: j.margeliene@kauko.lt, ausra.budriene@gmail.com
}

\begin{abstract}
Lithuanian red book were chosen and analyzed. The analysis revealed that the plants of a medium height (20 species) dominate. The flowers of 17 plant species are violet, and 48 species have green leaves. After analyzing bio ecological properties of rare plants it is possible to say heliouphilous plants dominate (37 species), majority of plants flower from the beginning of June until the end of August (50 species).

25 rare plants under research are allocated to category 2 (V) and are considered to be quickly extinct, endangered species, the population number of which and the number of individual plants decrease rapidly. The main reasons of the plant disappearance are the overgrowing of habitats by trees and bushes (58,18\%), irrigation and drainage (36,36\%) as well as intensive farming (29,09\%). The research identified that the main protective measures of rare plants are the support of the traditional farming, the limitation of hay harvesting and grazing, the maintenance of water hydro chemical, hydrological and hydrographic regime, etc.
\end{abstract}

Keywords: biological diversity, tax, anthropogenic activity, protection of rare plants, ecology, Lithuanian Red book.

\section{Introduction}

Lithuanian biological diversity includes about 30 thous. species of plants, mushrooms and animals. Over 2000 vascular plant species, the habitats of which are in the forests, fields, meadows, bogs, sandy places, live in the natural environment [7]. Three Red books have been published in Lithuania; they are the legal document, on the basis of which the protection of rare and disappearing plants is organized in the country. 30 endangered plant species were included in the first Red book in 1981 [2]. In 1992 the second Red book was published in Lithuania which included 210 plant species [3]. The third edition of the Red book included 339 endangered plant species in the year 2007 [ 4].

The year 2010 was the year of biological diversity, and encouraged everyone to take interest in plants included into the newest edition of Lithuanian Red book. First of all it is essential to get to know rare endangered plants because it determines their protection as the life of every specie is influenced by natural factors and nowadays anthropogenic activity in particular.

The third Red book includes descriptions of 3 Club mosses, 1 Horsetail, 8 Ferns, 1 Conifer, 221 Flowering plants, 1 Red algae, 1 Brown algae, 10 Charophytes, 93 Mosses. The plant species in Lithuanian Red book are divided into five categories according to the level of extinction $(0(\mathrm{Ex}), 1(\mathrm{E}), 2(\mathrm{~V}), 3(\mathrm{R}), 4(\mathrm{I}), 5(\mathrm{Rs}))$. Endangered plants are divided the following way: 14 into zero, 79 into first, 84 into second, 99 into third, 53 into fourth and 10 into fifth category. [4]. In the book plant species are described by analyzing their status (when the specie was included into the Red book for the first time), spread (taxon areal), biology and ecology (morphological properties and bio ecology), amplitude of populations (quantitative and qualitative indicators of the country population), threats and protection (the reasons for specie population state degradation and protection measures), map (spread of taxons represented using dot method) [4].

Today because of rapid decline in biological diversity the scientific aim to describe the present biodiversity before it finally disappeared is set. It is also important to provide conditions for the biodiversity survival. For the protection of biological diversity and 
sustainable resource management the convention of biological diversity was signed in Rio de Janeiro, Brazil, 1992. Every country should prepare national strategy for the preservation of biological diversity, integrated into the political tendencies of appropriate sectors. Special attention should be given to the preservation of biological diversity under natural conditions. For this purpose the system of protected territories has been created. Lithuania has also established the system of protected territories which allows to preserve biological diversity; they are reserves -6 , reserve parks -254 , national parks -5 , regional parks -30 [1].

The main goal of EU environmental protection policy is the protection of natural habitats and wild plants. There are 15 plant species in Lithuania included into the second annex of EU habitation directives [5].

The aim: To get to know rare and endangered Lithuanian plants and to identify their extinction reasons and methods of their protection.

\section{Materials and methods}

55 plant species included into the Lithuanian Red book (2007) were chosen and analyzed using J. Vaidelys (2005) methodology presented in the publication „Methodology of phonological observations, biometric measurements and assortment formation of ornamental herbaceous plants“ [6] and the information from the publication „Lithuanian Red book“, according to the following aspects:

1. assessment of morphological and bio ecological characteristics;

2. distribution of plant species according to categories;

3. identification of plant extinction causes;

4. identification of plant protection methods.

\section{Results}

Table 1 contains the data of morphological characteristics of rare.

Table 1.

Evaluation of morphological peculiarities of plants from Red Book of Lithuania

\begin{tabular}{|c|c|c|c|c|}
\hline No & Plant name & $\begin{array}{c}\text { Plant height, } \\
\text { cm }\end{array}$ & Leaf color & Blossom color \\
\hline 1. & Nymphaea alba L. & $70-80$ & green & white \\
\hline 2. & Nuphar pumium (Timm) DC. & $70-80$ & green & yellow \\
\hline 3. & Pulsatilla patens (L.) Mill. & 35 & green & violet \\
\hline 4. & Corydalis cava (L.) Schweigg. Et Korte & $20-30$ & green & violet \\
\hline 5. & Agrostemma githago L. & $50-100$ & grey & red \\
\hline 6. & Dianthus arenarius L. & $50-100$ & green & yellow \\
\hline 7. & Dianthus borbasii Vandas. & $30-50$ & green & red \\
\hline 8. & Dianthus superbus L. & $30-60$ & green & red \\
\hline 9. & Primula farinose $\mathrm{L}$. & $10-20$ & green & violet \\
\hline 10. & Viola uliginosa Besser. & $7-20$ & green & blue \\
\hline 11. & Alyssum gmelinii Jord. & $10-20$ & green & yellow \\
\hline 12. & Trifolium rubens L. & $20-80$ & green & violet \\
\hline 13. & Lathyrus laevigatus (Waldst. Et Kit.) Gren. & $20-60$ & green & yellow, red \\
\hline 14. & Astrantia major L. & $50-80$ & green & yellow \\
\hline 15. & Eryngium maritimum L. & $20-60$ & grey & yellow \\
\hline 16. & Scabiosa columbaria L. & $40-80$ & green & violet \\
\hline 17. & Succisella inflexa (Kluk) Beck. & 50 & green & violet \\
\hline 18. & $\begin{array}{l}\text { Centaurium littorale (Turner ex Sm.) } \\
\text { Gilmour }\end{array}$ & $3-15$ & green & red \\
\hline 19. & Gentiana pneumonanthe L. & $25-60$ & green & blue \\
\hline 20. & Gentianella amarella (L.) Borner & $15-40$ & green, brown & blue \\
\hline 21. & Nymphoides peltata (S. G. Gimel.) Kuntze & 200 & variegated & blue \\
\hline 22. & Polemonium caeruleum $\mathrm{L}$. & $35-120$ & green & blue \\
\hline
\end{tabular}




\begin{tabular}{|c|c|c|c|c|}
\hline No & Plant name & $\begin{array}{l}\text { Plant height, } \\
\text { cm }\end{array}$ & Leaf color & Blossom color \\
\hline 23. & Pulmonaria angustifolia $\mathrm{L}$. & $20-30$ & green & blue \\
\hline 24. & Linaria loeselii Schweigg. & $10-40$ & green & yellow \\
\hline 25. & Pedicularis sceptrum-carolinum L. & $30-80$ & green & yellow, red \\
\hline 26. & Ajuga pyramidalis $\mathrm{L}$. & $20-30$ & green & violet \\
\hline 27. & Scutellaria hastifolia L. & $10-40$ & green & blue \\
\hline 28. & Dracocephalum ruyschiana $\mathrm{L}$. & $40-60$ & green & blue \\
\hline 29. & Prunella grandiflora (L.) Scholler & $10-60$ & green & violet \\
\hline 30. & Salvia pratensis $\mathrm{L}$. & $20-80$ & green & Violet, blue \\
\hline 31. & Campanula bononiensis L. & $60-81$ & green & violet, blue \\
\hline 32. & Lobelia dortmanna $\mathrm{L}$. & $40-80$ & green & blue \\
\hline 33. & Centaurea phrygia L. & $60-81$ & green & violet \\
\hline 34. & Tragopogon Gorskianus Rchb. f. & $40-60$ & green & yellow \\
\hline 35. & Aster tripolium $\mathrm{L}$. & $40-60$ & green & violet \\
\hline 36. & Alisma lanceolatum With. & 100 & green & white \\
\hline 37. & Iris sibirica $\mathrm{L}$. & $30-80$ & green & Violet, blue \\
\hline 38. & Gladiolus imbricatus L. & $40-60$ & green & red \\
\hline 39. & Allium vineale $\mathrm{L}$. & $60-80$ & green & violet \\
\hline 40. & Gagea pratensis (Pers.) Dumort. & $10-20$ & green & yellow \\
\hline 41. & Allium angulosum L. & $15-40$ & green & white, yellow \\
\hline 42. & Allium ursinum $\mathrm{L}$. & $20-40$ & green & white \\
\hline 43. & Cypripedium calceolus L. & 50 & green & yellow, violet \\
\hline 44. & Cephalanthera logifolia (L.) Fritsch & $20-30$ & green & white \\
\hline 45. & Gymnadenia conopsea (L.) R. Br. & $30-60$ & green & violet \\
\hline 46. & Coeloglossum viride (L.) Hartm. & $20-30$ & striped & yellow \\
\hline 47. & Ophrys insectifera $\mathrm{L}$. & $20-60$ & green & $\begin{array}{l}\text { yellow with dark } \\
\text { edging }\end{array}$ \\
\hline 48. & Orchis mascula (L.) L. & $50-80$ & green & violet \\
\hline 49. & Orchis militaris L. & $10-20$ & green & violet \\
\hline 50. & Dactylorhiza incarnate (L.) Soo & $60-80$ & variegated & violet \\
\hline 51. & $\begin{array}{l}\text { Dactylorhiza ochroleuca (Wustnei ex Boll) } \\
\text { Holub }\end{array}$ & $60-80$ & green & white, yellow \\
\hline 52. & Liparis loeselii (L.) Rich. & $15-20$ & green & yellow \\
\hline 53. & Bolboschoenus maritimus (L.) Palla & $10-30$ & green & dark brown \\
\hline 54. & Eriophorum gracile W. D. J. Koch ex Roth & $15-25$ & green & white \\
\hline 55. & Hammarbya paludosa (L.) Kuntze & $10-20$ & green & white \\
\hline
\end{tabular}

The height of the researched plants is given in picture 1 .

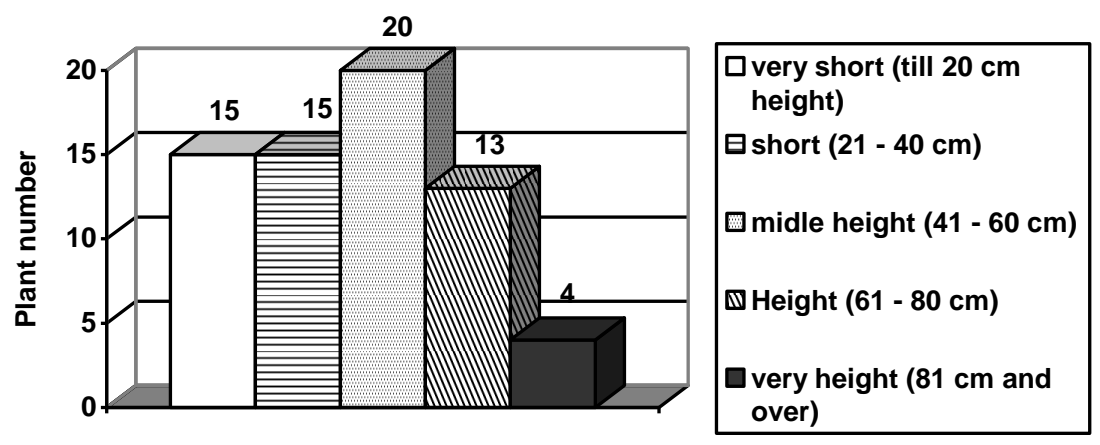

Fig. 1. Plant height

From the data presented (picture 1) it is obvious that the plants of a middle height dominate 20 plants: Dianthus borbasii, Aster tripolium, Dianthus superbus, Tragopogon Gorskianus, Scabiosa columbaria etc. There are 15 short plants: Allium angulosum, Gentianella amarella, Allium ursinum, Linaria loeselii, Scutellaria hastifolia etc. There are 15 very short plants: Liparis loeselii, Hammarbya paludosa, Alyssum gmelinii, Orchis militaris etc. 
The flower color of the plants is presented in picture 2 .

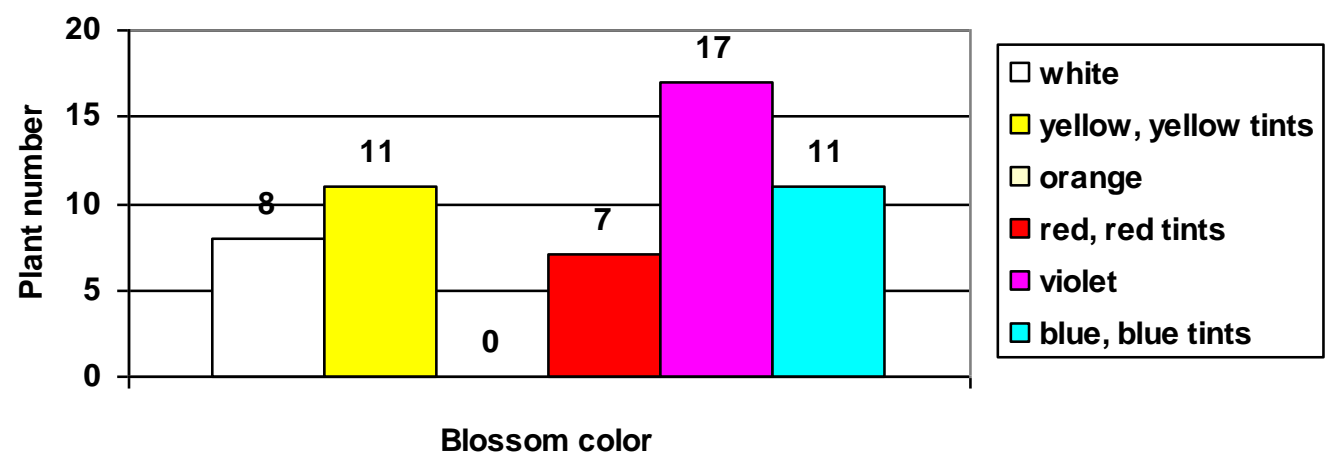

Fig. 2. Plant blossom color

Diagram (picture 2) shows that the prevailing color of the endangered plants, included into Lithuanian Red book, is violet - 17 plants. (Linaria loeselii, Centaurea Phrygia, Succisella inflexa, Allium vinele, Pulsatilla patens etc). 11 plants have yellow blossoms: Liparis loeselii, Cypripedium calceolus, Nuphar pumium etc.

The range of plant leaf color is given in picture 3. It is natural that the green leaf color dominates among the plants (48 plants).

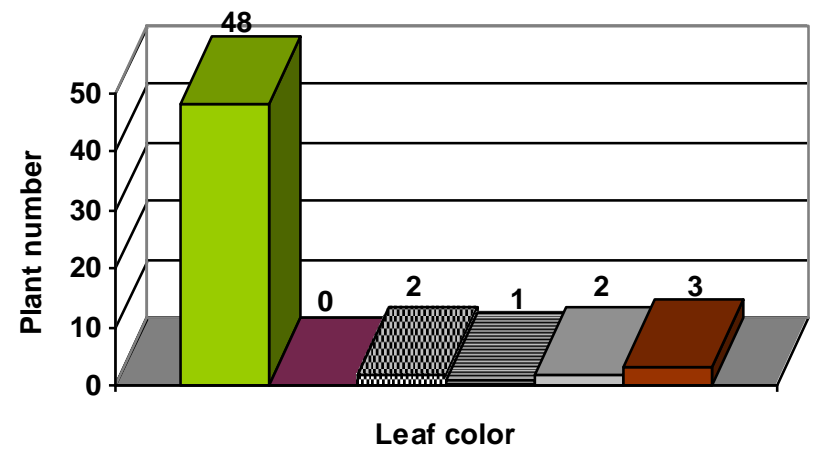

\begin{tabular}{|l|}
\hline$\square$ green \\
$\square$ purple \\
W variegated \\
貝 striped \\
$\square$ grey \\
$\square$ brown \\
\hline
\end{tabular}

Fig. 3. Plant leaf color

The need for light of the plants is presented in picture 4 .

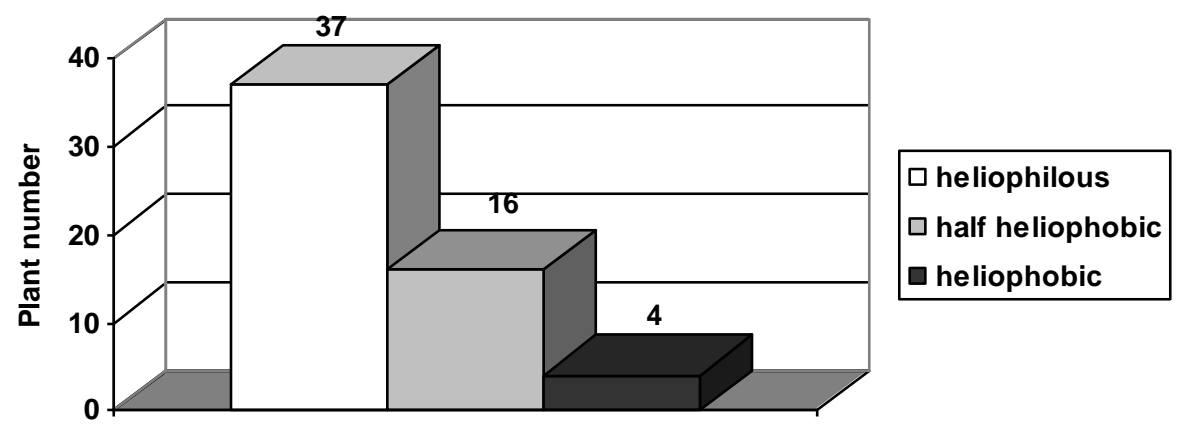

Fig. 4. Plant lightening

Picture 4 shows that majority of plants are heliouphilous (37 plants.): Dactylorhiza ochroleuca, Prunella grandiflora, Nymphoides peltata, Centaurium littorale etc. There are 
fewer plants that grow in a shade (16 plants.): Hammarbya paludosa, Coeloglossum viride, Allium ursinum, Corydalis cava etc.

Evaluation of plant blooming time is given in picture 5 .

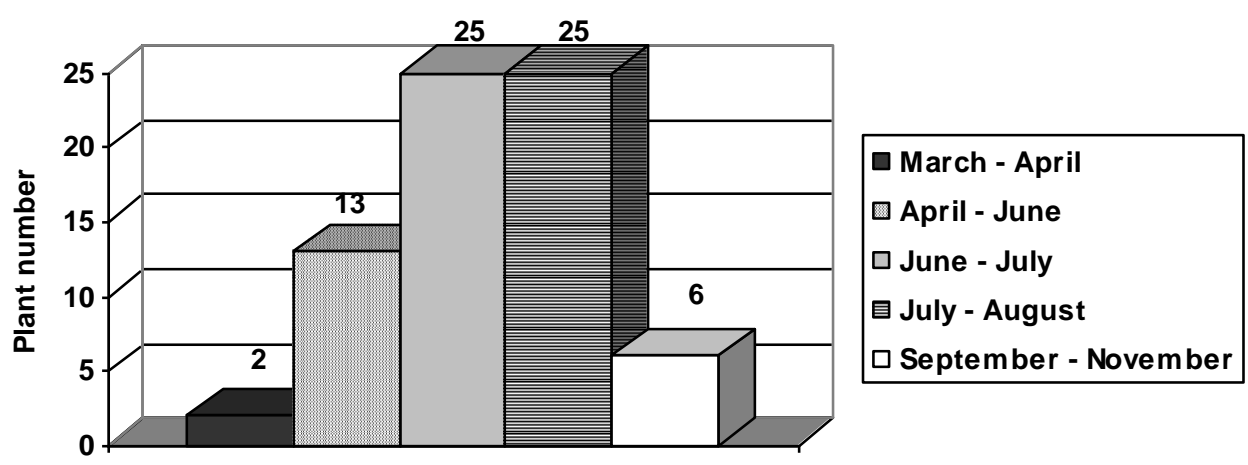

Fig. 5. Plant blooming time

In Lithuania endangered plants most often bloom from June till August (50 plants): Ophrys insectifera, Scutellaria hastifolia, Nymphaea alba, Dianthus arenarius etc. There are fewer plants that bloom from April till June (13 plants): Coeloglossum viride, Iris sibirica, Pulmonaria angustifolia etc.

The analysis revealed that 25 plants are allocated to category $2(\mathrm{~V})$ and are quickly becoming extinct, endangered species, the number of populations and individual plants of which is decreasing rapidly.

The majority of rare plants become extinct because of overgrowing of habitats by trees and bushes $(58,18 \%)$, irrigation and drainage $(36,36 \%)$ as well as intensive farming $(29,09 \%)$. The less threat is caused by grazing $(21,82 \%)$, plant picking for medicine and plant cutting $(20 \%)$ and grass stab $(16,36 \%)$.

The main protective measures of rare plants are the following:

1. The support of the traditional farming, the limitation of hay harvesting and grazing.

2. The maintenance of water hydro chemical, hydrological and hydrographic regime.

3. The maintenance of open areas, their protection from overgrowing.

4. Limitation of farming and recreational activity.

5. Limitation of clean forest fellings.

6. Artificial restoration of species.

\section{Conclusions}

After assessing morphological properties of 55 endangered plant species it was identified that the plants of a middle height dominate (20 species), even 17 plant species have violet blossoms; and green color leaves characteristic to 48 plant species. After researching the bio ecological properties of rare plants it is possible to say that the heliouphilous plants prevail (37 species) that bloom from the beginning of June till the end of August (50 species).

The analysis of rare plants showed that the majority of researched endangered plants belong to the $2(\mathrm{~V})$ category and are fast disappearing endangered species the number of populations and individual plants of which is decreasing rapidly.

The main reasons of the plant disappearance are the overgrowing of habitats by trees and bushes $(58,18 \%)$, irrigation and drainage $(36,36 \%)$ as well as intensive farming $(29,09 \%)$. The research identified that the main protective measures of rare plants are the support of the traditional farming, the limitation of hay harvesting and grazing, the maintenance of water hydro chemical, hydrological and hydrographic regime, etc. 
Margelienė J., Budrienė A. ANALYSIS OF PLANTS INCLUDED INTO LITHUANIAN RED BOOK

\section{References}

1. Kirstukas M. Lietuvos gamta. Saugomos teritorijos. Kaunas, 2004. 391 p.

2. Lietuvos TSR raudonoji knyga. Retosios ir nykstančios gyvūnų bei augalų rūšys. Vilnius, 1981. 82 p.

3. Lietuvos raudonoji knyga. Vilnius, 1992. 364 p.

4. Lietuvos raudonoji knyga. Kaunas, 2007. 799 p.

5. Raudonikis L. Europos Sajungos Buveinių direktyvos Saugomos rūšys. Vadovas. Kaunas, 2006. 101 p.

6. Vaidelys J. Dekoratyviujų žolinių augalų fenologinių stebejjimų, biometrinių matavimų ir sortimento sudarymo metodika. Mastaičiai, 2005. 82 p.

7. Vilkonis K. Lietuvos žaliasis rūbas. Kaunas, 2001. 415 p. 